\title{
Cultural Landscape Preservation in Bosnia and Herzegovina in the Frame of Tourism Development
}

\author{
Lana Kudumovic \\ Fatih Sultan Mehmet Vakif University, Istanbul, Turkey
}

\begin{abstract}
This paper focuses on the linking of heritage preservation policies and tourism development, specifically in relation to the cultural landscapes. For this purpose, historic ensembles Blagaj, Jajce and Travnik, that have emerged from the integration of cultural and natural elements are discussed, in particular, the existing plans and legislation related to heritage preservation and tourism strategies. Also, the extent to which tourism strategies are oriented toward heritage is measured through analyzed promotional materials and touristic offers.

In the conclusion, the potential for tourism development ensuring the sustainability of these historic sites is given in a closing suggestions and remarks.
\end{abstract}

Keywords - Cultural landscape, tourism, heritage preservation.

\section{Introduction}

Historic sites and their diverse components are considered valuable assets and are the inheritance of future generations. Beside its direct relationship with cultural identity, well preserved cultural heritage has the potential to become a tourist attraction and thus contribute to economic development. [1] In the twenty-first century, across the world, cultural heritage has fast become a vital component of any strategy of tourism development.

DOI: $10.18421 /$ TEM92-42

https://doi.org/10.18421/TEM92-42

Corresponding author: Lana Kudumovic,

Fatih Sultan Mehmet Vakif University,

Faculty of Architecture and Design, Istanbul, Turkey.

Email: lkudumovic@fsm.edu.tr

Received: 09 March 2020.

Revised: 30 April 2020.

Accepted: 07 May 2020.

Published: 27 May 2020.

(c) BY-NC-ND (C) 2020 Lana Kudumovic; published by UIKTEN. This work is licensed under the Creative Commons Attribution-NonCommercial-NoDerivs 4.0 License.

The article is published with Open Access at www.temjournal.com
Cultural landscapes are among the most interesting heritage sites for tourism development as they include diverse features. They form a particular heritage category that is distinguished by an inseparable combination of natural and cultural values. A site of this type, in essence, encompasses an area that contains more than just built heritage and is rather the result of the common work of man combined with nature. A cultural landscape "includes notably the site's topography, geomorphology, hydrology and natural features, its built environment, both historic and contemporary, its infrastructures above and below ground, its open spaces and gardens, its land use patterns and spatial organization, perceptions and visual relationships, as well as all other elements of the urban structure. It also includes social and cultural practices and values, economic processes and the intangible dimensions of heritage as related to diversity and identity" [2]. Additionally, such sites are enriched by cultural activities, which can add significant value.

In Bosnia and Herzegovina, tourism is a fast growing area with great potential to contribute to the country's overall economy. The rich cultural heritage of Bosnia and Herzegovina is of particular interest for tourism development, especially in relation to those assets of high cultural and historical value and particularly for those historic urban settings that are integrated with natural environments. According to the State Tourism Agency of Bosnia and Herzegovina, the types of tourism offered in the country include various sporting attractions and visiting local natural and cultural sites during both winter and summer. Currently, the destinations most visited by international tourists are Sarajevo and Mostar.

Statistics show that the number of tourist visits in the Federation of Bosnia \& Herzegovina in 2017 increased by $60 \%$ in comparison to the number recorded in 2014 [3]. Even though tourist visits have been increasing lately, generally not enough has been done to increase tourism. On the contrary, strategies for tourism developments are still quite fragmented as a result of complex governing policies in the country, set after the 1992-1995 war. Therefore not 
enough attention has been paid to comprehensive tourism strategies, which would also include heritage to allow for general development to take place.

In brief, tourism strategies mostly only mention the importance of heritage, or else present the current condition of these sites in terms of statistical analyses, specifically SWOT (strengths, weaknesses, opportunities, and threats) analyses. Strategies have also been overwhelmed by the demands of a complex stakeholder system. Many historic structures are owned by waqf (charitable endowments regulated by Islamic law) and churches, or are privately owned. Ownership is also by state and public institutions. Being designated national monuments, they are directly regulated at the state level, but any action related to these properties has to pass through cantonal and municipal levels too and many times these actions do not correlate well with each other.

This paper will present three historic ensembles: Blagaj, Jajce, and Travnik. which are among the most famous tourism destinations in the country. These places have the special character and unique appearance characteristic of cultural landscapes. The historic ensembles of Jajce and Blagaj are the result of man-made activities within a natural environment, contributing to their beauty and uniqueness, while in Travnik, the old historic core has been enlarged to include the site of Plava Voda (Blue Water: a large spring with surrounding historic structures). These places integrate both the remains of the past and the natural environment, offering unique settings for the settlements. The policies and strategies applied to the heritage preservation of each site have primarily focused on individual structures, while on the ground urban conservation policies have yet to be developed.

For the selected sites, cultural heritage preservation is an important driver of future development, while tourism is potentially an important catalyst for the safeguarding of historic fabric and the initiation of conservation on an urban scale [4]. In Bosnia, state tourism strategies have not yet brought about a tourism boom and nor have the municipalities involved ensured the sustainability of these destinations. Most of the tourist offers are very basic, with a lack of infrastructure (accommodation, services, facilities etc.) and limited promotion. Even though some of the strategies developed at the level of the local municipalities mention the potential for enlarging tourism visits to take in a wider area, providing varied points of cultural interest and integrating intangible and tangible heritage, such strategies have not yet been completely realized.

\section{Historic Ensembles of Blagaj, Travnik, and Jajce: A Vision for Cultural Landscapes}

The historic ensembles of Blagaj, Travnik, and Jajce developed along river channels with neighbourhoods that built up over time. The sites are structured as logical responses to the natural conditions. They are part of the rich history of Bosnia: the result of long historical processes and their natural settings, which contribute to their uniqueness and distinctiveness. At the highest point of all three, fortifications-walled defensive structures - are located, the history of these places is inscribed in their strong stone walls. Additionally, their urban fabric is enriched with different types of historic building, monuments, and natural attractions, while in their close vicinity there are cultural or natural attractions of special importance. (Table 1.)

The rivers are inseparable elements of these historic ensembles. Together with many national monuments in close proximity to each other, they offer the potential for the development of tourist tours connecting all the elements of these sites. These in turn could be expanded to connect with cultural and natural attractions in surrounding areas.

Table 1. Cultural and natural heritage features in Blagaj, Jajce, and Travnik (according to the List of National Monuments)

\begin{tabular}{|c|c|c|c|c|}
\hline$\frac{\mathscr{U}}{\frac{\pi}{2}}$ & 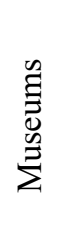 & 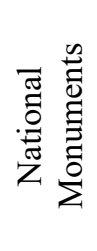 & 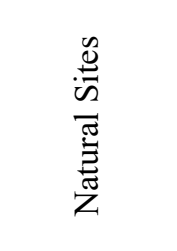 & 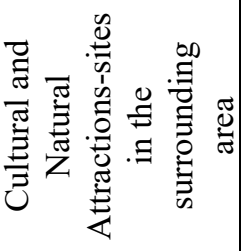 \\
\hline 每 & 2 & 10 & River Buna & $\begin{array}{l}\text { Cave Zelena } \\
\text { pećina }\end{array}$ \\
\hline 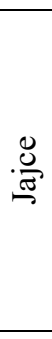 & 2 & 23 & Lake Pliva & $\begin{array}{c}\text { Cultural } \\
\text { landscape at } \\
\text { Pliva lake } \\
\text { with mills; } \\
\text { Mediaeval } \\
\text { fortresses of } \\
\text { Vinac and } \\
\text { Komotin. } \\
\end{array}$ \\
\hline 弟 & 3 & 11 & $\begin{array}{l}\text { Cultural } \\
\text { landscape } \\
\text { of Plava } \\
\text { Voda }\end{array}$ & $\begin{array}{c}\text { Vlašić } \\
\text { Mountain; } \\
\text { other close } \\
\text { municipalities }\end{array}$ \\
\hline
\end{tabular}




\subsection{Blagaj, Travnik and Jajce: Brief Historic Background of Historic Ensembles}

Blagaj is a historic place in Herzegovina, characterized by a Mediterranean climate and located on the banks of the Buna River. Archaeological remains indicate that human activity and settlement has taken place in the area since prehistoric times. The fortress at Blagaj is a complex of several strata displaying its development and upgrading in different historical periods. The first structures date back to the 4th century $\mathrm{AD}$, the period of late antiquity [5]. In the Middle Ages, Blagaj was named Stjepan grad after the ruler Stjepan Kosača, and was built on the foundations of the fourth-century structure [6]. After 1465, Blagaj came under Ottoman administration and the urban setting was developed [7]. The River Buna acted as an axis of urban development. The centre was a place of public functions, trade, and crafts. After 1878, Blagaj lost its importance under the Austro-Hungarian administration.

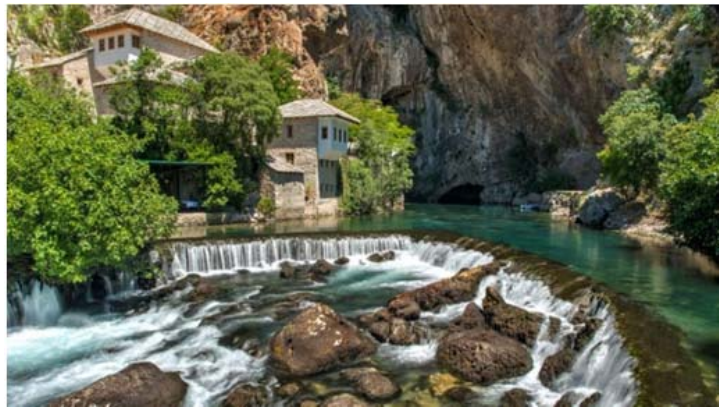

Figure 1. The tekke in Blagaj located below the cliff at the spring of the Buna River ${ }^{1}$

The tekke located at the base of the cliffs at the site of the source of the Buna River is a key tourist feature in Blagaj. Its architectural value has long been recognized as is shown by the 16th century religious structure constructed here, which displays clear influence of Mediterranean architectural styles. The sense of spirituality is enhanced by its integration with the natural elements of water and an imposing rockface. Similarly, an expression of local virtuosity is seen in the use of nature to enhance the design and function of the residential complex of Velagićevina, which is arranged along the river. A wall encompasses several buildings with different functions (traditional houses, stores, mills, animal pens, etc.), which are connected with courtyards and gardens. These structures are the product of spontaneous development combined with natural surroundings.

Travnik is located in the valley of the River Lašva and is a good example of a town in the central part of the country. The area around Travnik has been

\footnotetext{
${ }^{1}$ https://www.shutterbug.com/content/vrelo-bune-springriver-buna
}

inhabited since the Neolithic period. The fortress is an early Middle Age structure built before 1463 [8]. Suburbs under the fortress have seen intense development since the 15th century, under the Ottoman administration. After Sarajevo was sacked in 1697 by Prince Eugene of Savoy, Travnik became the capital of the Bosnian Pasaluk from 1699 until 1850 [9]. Development of the central part, the charshi (bazaar), saw the construction of mosques, madrassas (schools), hammam, han, bezistan (shopping centres), water systems, and public faucets. It is known that Travnik had 16 mosques and two clock towers [10]. Many of the public buildings, houses, and shops in the market, as well as complete residential quarters on the left bank of the River Lašva, disappeared in the fire of 1903. The vernacular residential architecture typical of Travnik used high pitched roofs covered with wooden shingles. Today, most of these houses have lost their original form. After 1878, the new Austro-Hungarian rulers brought changes, such as industrial development and a railroad. A similar trend in urban development was seen from the world wars onwards. Plava Voda is a green oasis that acts as a natural extension of the historic core.

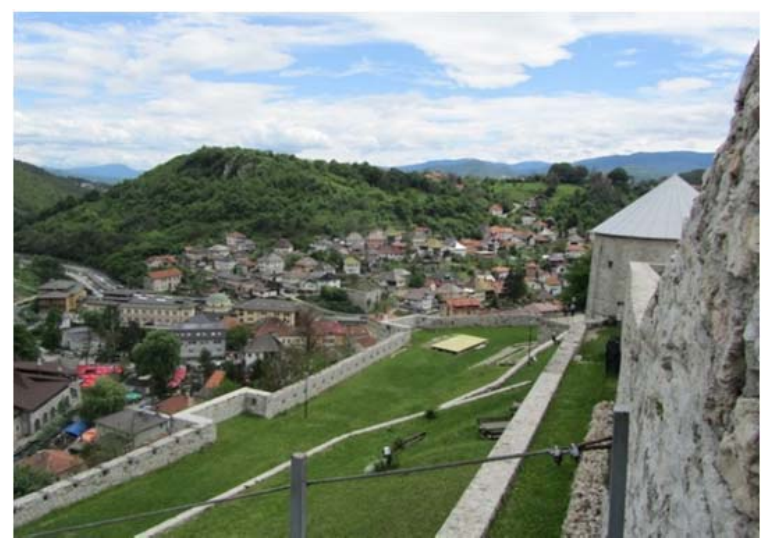

(a)

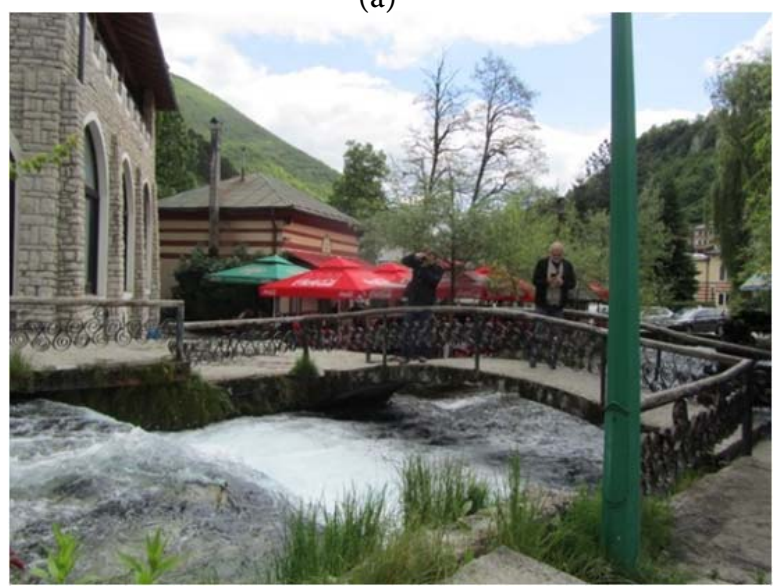

Figure 2. Travnik: view from the fortress (a) and Plava Voda (b) (Source: author)

Jajce is located in the central region of Bosnia and Herzegovina at the confluence of the rivers Pliva and 
Vrbas. The most ancient traces of human activity in Jajce date from the Chalcolithic period (in the locality of Varošnice). The old town has a fortress, town ramparts, and towers, which are linked to Vukčić Hrvatinić who became its ruler in 1366 [11]. The Ottomans took Jajce in 1463. In the period between 1464 and 1528, Jajce was the seat of the Jajce Banate. During the Ottoman period, Jajce was designated as a captaincy (Kapetanija).

The historic core of Jajce is arranged along the steep slopes at the foot of the hill, above waterfalls and the rocky tufa cliffs that make up the banks of the Pliva and Vrbas rivers. The area along the two rivers has distinctive biological features that contribute to the overall image of the space. The market (charsi) was constructed on the site of the mediaeval market with rows of small wooden shops. Jajce was also an administrative centre and various public buildings were built while others that already existed were given new functions. Residential quarters were set on the slopes below the castle. Houses dating to the period between the 16th and19th centuries make up a big part of the urban fabric. They were built as simple cubic structures, with pyramidal, high pitched roofs and highlighted canopies and covered with wooden shingle.

Until 1878, there was no kasaba (small settlement) or town outside the ramparts [12]. After 1878, the Austro-Hungarian administration came to power and, as was the case for other towns in Bosnia, industrial facilities were built in Jajce (on the right bank of the River Pliva and the left bank of the River Vrbas). The town saw a certain amount of spatial reorganization, but building activity was not particularly intense despite the novelty of a new architectural style. In 1943, during World War II, the Anti-fascist Council for the National Liberation of Yugoslavia (AVNOJ) met in Jajce, where the Federal state of Yugoslavia was established.

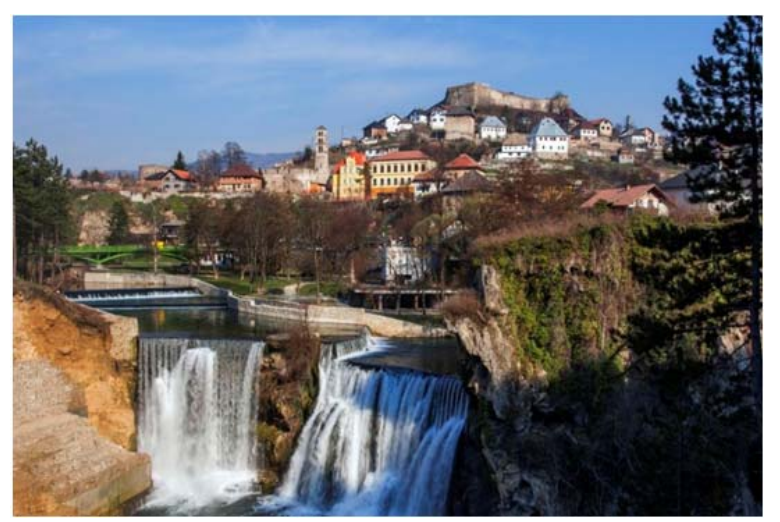

Figure 3. Jajce historic core above the waterfall ${ }^{2}$

\footnotetext{
${ }^{2}$ https://www.viadinarica.com/en/component/content/artic e?id=129:a-green-trail-photo-essay-jajce-and-the-sipovoeco-zone
}

\section{The Historic Ensembles of Blagaj, Travnik, and Jajce: Current Status and Policies in Relation to Tourism}

The historic cores (Blagaj, Jajce) or their parts (Travnik) have been assigned the status of National Monument of Bosnia and Herzegovina by the Commission to Preserve National Monuments, with designated protected borders and buffer zones. Additionally, some individual historical structures located within have been proclaimed national monuments as well. For all three cases, recommended and permitted interventions for heritage preservation are defined by the Designation of the Commission, as well as by some of the existing plans that will be mentioned further in the text. These have not resulted in sufficient preservation of the integrity and authenticity of these places. Most preservation activities are rather isolated and focused on single structures.

The border of the protected site of Blagaj's historic urban area is quite a small strip along the Buna River [7]. Since 2007 it has been inscribed on the UNESCO tentative list. The regulatory plan for Blagaj, prepared for the period between 2011 and 2021, deals with land use and building analyses and provides basic concepts for the development of the locality. The plan integrates recommendations defined by the Decision on Designation as National Monuments. The regulatory plan for Blagaj was approved by the Parliamentary Assembly of Bosnia and Herzegovina in 2017. This plan establishes a foothold in legal regulation for future interventions and promotes the idea that the proposed conservation area should include all valuable elements, including natural components and surroundings, between the fortress and the river.

The historic urban area of Jajce is designated a National Monument of Bosnia and Herzegovina and displays features of monumental, historical, architectural, and environmental value. The designation defines the boundaries of the historic core of Jajce and three levels of protection accordingly.

Recognizing the outstanding universal importance of the historic area of Jajce, in 2007 it was listed on the Tentative UNESCO World Heritage List (WHL). The municipality of Jajce, together with the Commission to Preserve National Monuments, has prepared a management plan, which is an obligatory document for inscription on the UNESCO WHL. The management plan defines proposals for tourism around cultural, historical, and religious heritage and natural attractions, and emphasizes the need for proper presentation and interpretation of this heritage [13]. 
Currently, the General Zoning Plan 1968-71 for Jajce is still in use. The plan indicates the historic core and all the valuable elements to be protected. Together with several other regulatory plans, this still forms the basis for regulating urban processes within the municipality. Within the Strategy for the Development of the Municipality of Jajce 2014-2023 [14], some of the mentioned goals include the recovery of tourism infrastructure and the creation of traditional tourism products. It also mentions that these strategies are in line with other plans, such as the document on Strategies for Tourism Development in FB\&H 2008-2018 and Development of Industrial Politics of FB\&H [14]. The development of tourism infrastructure and tourism products are counted among 27 assigned projects.

Since 1998, many activities have been performed as part of a post-war recovery effort while the abovementioned documents do not give a clear picture of the current situation and do not provide a base for comprehensive urban enhancement or adequate conservation.

In Travnik, in addition to a number of individual structures and the fortress, the old Lutfiana (Rudolfs) Café building and the tombs of Travnik's Mufti, Mehmed Efendi, and his spouse, Ajiša Hanuma, located at the edge of the urban area, together with the natural setting of the spring Plava Voda are inscribed as national monuments under the category of cultural landscape [15]. This designation includes proposed protective measures for the monuments according to which only conservation and restoration are allowed for structures, as well as maintenance. Furthermore, the building of any new structure in the area of a national monument is prohibited and it is suggested that measures to decrease the impact on the cultural landscape in the regulatory plan of the historic zone are included. On the other hand, most of the historic monuments dating back to the Ottoman and the Austro-Hungarian periods are located within the historic core, and the majority of these are under state protection as National Monuments of Bosnia and Herzegovina.

Currently, regulation of the historic zone relies on the existing regulatory plan, which was prepared in the 1980s; it has not been updated properly, apart for some studies undertaken by various parties. This has led to damaging alterations of the urban fabric, including the Plava Voda site, and leaves the area with no guidelines for protective measures that enhance the historic sites. The strategies for tourism development laid out by Travnik Municipality mention that there is no established cultural tourism route that takes in the historic core or the wider area [16].
All three sites Blagaj, Travnik and Jajce, lack a tourism plan to support sustainable use of the heritage assets or else intangible heritage. Inside these sites, presentations of intangible heritage are mostly limited and scarce, or exhibited in local museums as movable artefacts, while no interactive exhibition is available for sites.

\subsection{Heritage and Tourism Promotion Strategies}

Linking tourism with heritage offers the possibility of fostering heritage conservation and properly presenting historic sites and monuments to visitors.

Cultural landscapes are large heritage assets that can facilitate a variety of tourist attractions, including different customs and traditions.

“...the values associated with monuments and sites should also be considered as intangible cultural heritage (as defined under UNESCO's 2003 Intangible Heritage Convention) when they belong to the living heritage of present-day communities. Hence the identification of intangible cultural heritage in the urban context needs involvement of local communities. Its preservation and promotion, however, requires a connection between different fields of public policy linking education and skills training in the arts and crafts to local tourism development..." [17].

The International Cultural Tourism Charter defines domestic and international tourism as among the foremost vehicles of cultural exchange. It also states that conservation should provide responsible and well managed opportunities for members of the host community and visitors to experience and understand the community's heritage and culture first-hand. It also implies the importance of programmes for public awareness, heritage interpretation, and presentation [18].

Orbasli [4] explained that the Tourism can become a valuable means for widening cultural understanding to include less valued monuments and overlooked traditional urban environments. In many instances tourist interests have activated conservation programmes for archaeological sites, monuments or vernacular buildings, and, more recently, entire urban areas.

The three selected sites regularly see school visits and are also important stopping points on main roads. The discussed towns are known for their natural and historic structures and are therefore already tourist attractions. How citizens of $\mathrm{B} \& \mathrm{H}$ perceive those towns (Figure 4.), embracing the built or natural elements, can be seen in the answers given to a few simple questions. 


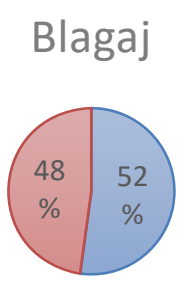

Travnik

口Buna $\square$ Tekke $\square$ Plava voda $\square$ Sarena Mosque

\section{Jajce}
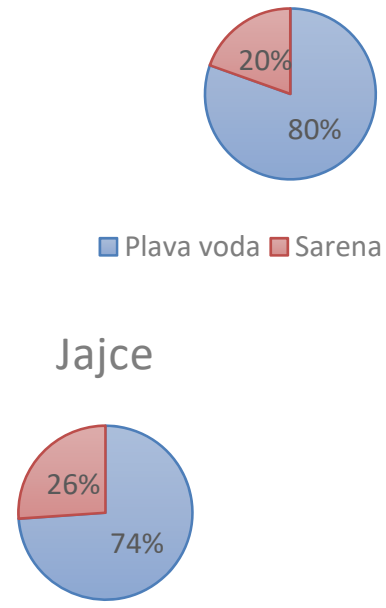

Waterfall $\square$ Fortress
A group of primary school students (11-14 years old) were asked to make associations between the three selected sites: Blagaj: River Buna/tekke; Travnik: Plava voda/Sharena Mosque; Jajce: waterfall/fortress.

Furthermore, the present available information about means for promotion are collected from the websites of the state bodies in charge of tourism in Jajce, Travnik, and Blagaj and summarised in Table 2. From the results shown in the table it can be concluded that the tourist potential is not yet at full capacity.

Figure 4. Results of questions on site association for Travnik, Blagaj, and Jajce among primary school children (source: Author)

Table 2. Analyses of promotion on the official web pages of the governmental bodies for tourism promotion in Travnik, Blagaj, and Jajce (source: Author)

\begin{tabular}{|c|c|c|c|c|c|}
\hline Web page & Brochure & Maps & $\begin{array}{l}\text { Offered no. of } \\
\text { accommodation }\end{array}$ & $\begin{array}{l}\text { Heritage } \\
\text { promotion }\end{array}$ & $\begin{array}{l}\text { Program of } \\
\text { visits (related to } \\
\text { heritage) }\end{array}$ \\
\hline $\begin{array}{l}\text { Tourist community of Herc. } \\
\text { Neretva Canton-Blagaj } \\
\text { https://www.hercegovina.ba }\end{array}$ & $\begin{array}{l}\text { Mentioned in } 4 \\
(2014 \text { and } \\
2015)\end{array}$ & 1 & 1 & 1 & $\begin{array}{l}1 \text { map of } \\
\text { cultural heritage } \\
\text { route } \\
1 \text { map of agro- } \\
\text { tourism } \\
1 \text { general map } \\
\text { of sites of } \\
\text { interest in } \\
\text { Herzegovina }\end{array}$ \\
\hline $\begin{array}{l}\text { Mostar Municipality-Tourism } \\
\text { portal } \\
\text { https://www.turizam.mostar.ba }\end{array}$ & $T$ & $T$ & 1 & $\begin{array}{l}\text { Basic } \\
\text { information } \\
\text { about site }\end{array}$ & 1 \\
\hline $\begin{array}{l}\text { Agency Jajce } \\
\text { www.agencija-jajce.ba }\end{array}$ & 1 & 1 & 8 & $\begin{array}{l}\text { Detailed } \\
\text { information } \\
\text { about sites }\end{array}$ & I \\
\hline $\begin{array}{l}\text { Tourist community of Srednie- } \\
\text { Bos. Canton-Travnik } \\
\text { http://www.tzsbk.com }\end{array}$ & I & 1 & 8 & \multirow{2}{*}{$\begin{array}{l}\text { Brief } \\
\text { information } \\
\text { about all } \\
\text { sites }\end{array}$} & 1 \\
\hline $\begin{array}{l}\text { Tourist community of Srednie- } \\
\text { Bos. Canton-Jaice } \\
\text { hittp://www.tzsbk.com }\end{array}$ & I & 1 & 3 & & 1 \\
\hline $\begin{array}{l}\text { Touristic community of } \\
\text { Federation B\&H } \\
\text { http://www.bhtourism.ba/loc/ }\end{array}$ & $\begin{array}{l}\text { Magazine from } \\
2010\end{array}$ & 1 & 0 & $\begin{array}{l}\text { Brief } \\
\text { information }\end{array}$ & I \\
\hline $\begin{array}{l}\text { Visit Jaice-NGO } \\
\text { www.visitjajce.com } \\
\end{array}$ & Web application & $\begin{array}{l}1 \\
\text { plus } \\
\text { interactive } \\
\text { map }\end{array}$ & 2 & $\begin{array}{l}\text { Detailed } \\
\text { information } \\
\text { about sites }\end{array}$ & $\begin{array}{l}2 \text { museum and } \\
\text { cultural heritage } \\
\text { sites } \\
4 \quad \text { cultural } \\
\text { events } \\
\end{array}$ \\
\hline
\end{tabular}


Information drawn from the World Wide Web, in particular the Tripadvisor website, highlights internationally offered tours in relation to the culture and heritage of Jajce, Travnik and Blagaj under the following categories: cultural; historic \& heritage; literary, art \& music; architectural; and archaeological. The number of each can be seen in Table 3. The tours offered have been created by private initiatives and tour operators.

The tours offered are mostly visits of between 2 hours and one day duration, travelling from larger centres such as Mostar and Sarajevo. Summarized data indicates a lack of sufficient infrastructure, such as a lack of accommodation and or sufficiently diverse activities to prolong tourism visits.

Table 3. Types of tours related to the heritage of Jajce, Travnik and Blagaj offered in Tripadvisor ${ }^{3}$ in 2019. (source: Author)

\begin{tabular}{|c|c|c|c|}
\hline Tripadvisor & Jajce & Travnik & Blagaj \\
\hline Cultural Tours & 14 & 13 & 54 \\
\hline $\begin{array}{c}\text { Historical \& } \\
\text { Heritage Tours }\end{array}$ & 16 & 16 & 65 \\
\hline $\begin{array}{c}\text { Literary, Art \& } \\
\text { Music Tours }\end{array}$ & $/$ & $/$ & 1 \\
\hline $\begin{array}{c}\text { Architecture } \\
\text { Tours }\end{array}$ & $/$ & $/$ & 1 \\
\hline $\begin{array}{c}\text { Archaeology } \\
\text { Tours }\end{array}$ & $/$ & $/$ & 6 \\
\hline
\end{tabular}

In summary, the current status of the three sites in relation to the tourism offer can be summarized to as follows: products; lack of services; poor infrastructure; unregulated traffic, paths and trails; no activities along the river; insufficient maintenance and presentation of heritage properties.

Weaknesses: no branding and strategies; weak promotion; unregulated selling of souvenirs and local

Opportunities: developing a network of heritage nodes; activation of new points of interest; potential for heritage route inside historic ensemble and together with wider area.

Strengths: variety of heritage attractions; unique natural environment; reasonable urban and population density.

Threats: heritage site deterioration; loss of local population; inappropriate heritage usage and presentation that endanger heritage values.

\section{Case of Blagaj}

To illustrate the limited movement inside the sites, axes of tourist movement and spontaneously created tourist paths, as well as possible development of points of interest at the site of Blagaj were analysed.

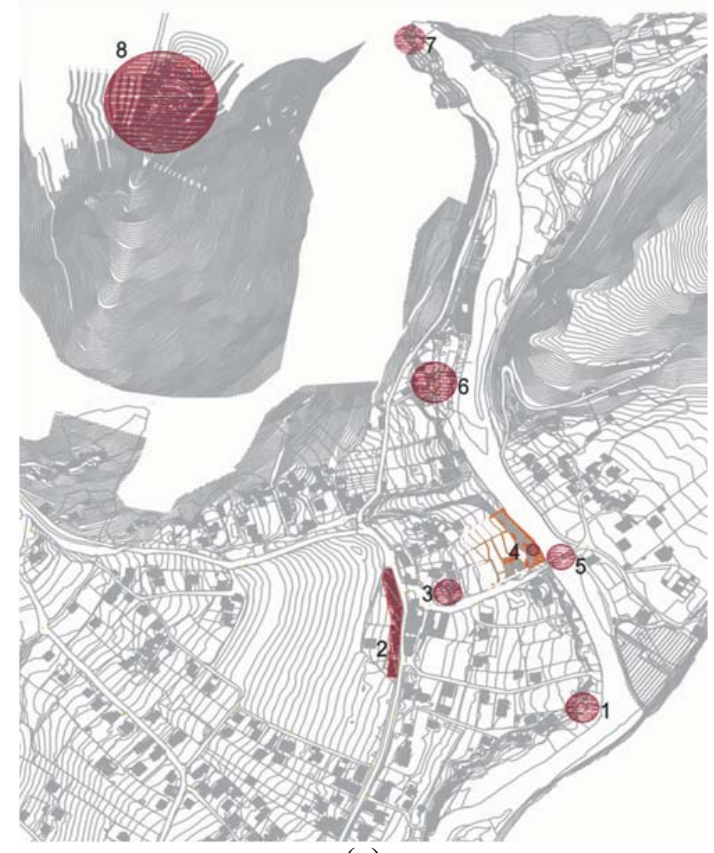

(a)

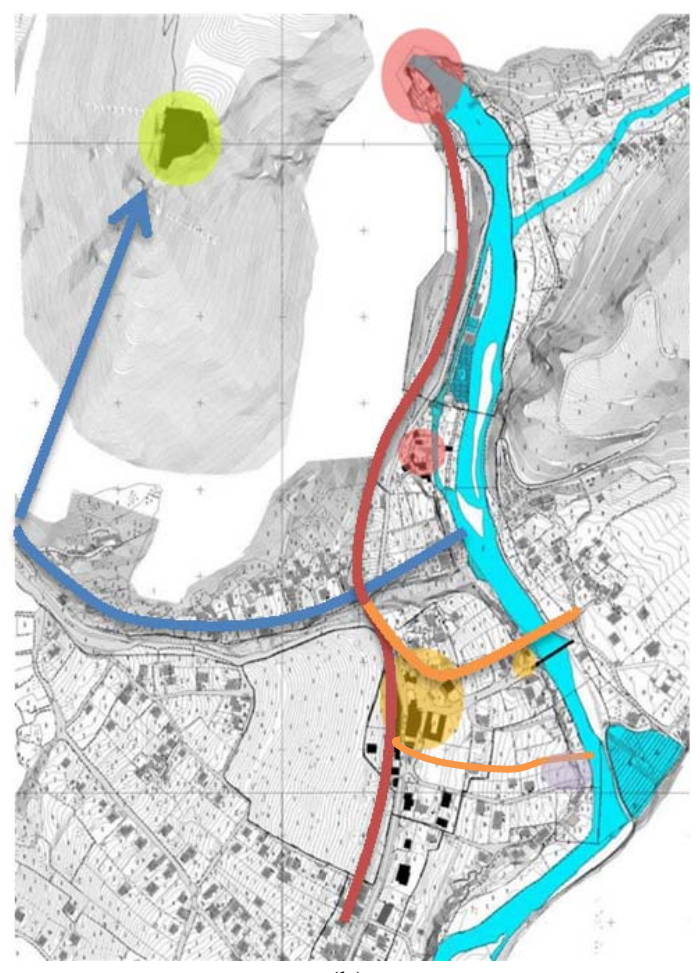

(b)

Figure 5. Blagaj main axis (b) and points of interests (a) (Source: author)

\footnotetext{
${ }^{3}$ www. tripadvisor.com
} 
Maps (figure 5.) indicate that the current main axis is set parallel to the River Buna starting from the entrance to the town and ending at the tekke. It is shown as the primary direction on the map (right map, red line). Along this axis, tourists are mostly concentrated from the Velagicevina house complex (point 6-left map) to the tekke (point 7-left map). The secondary direction (right map, blue line) goes towards the fortress (point 8-left map) with very few other points of interest along the road. According to the present situation and the potential of the site, the third axis (right map, green line) traversed by visitors can be set to include the hammam (point 4-left map), the Karadjozbeg Bridge (point 5-left map), the Sultan Sulejman Mosque (point 3-left map), and the Kolakovica housing complex (point 1-left map).

With idea to activate seven main economic activities (accommodation; food and beverage; transportation; intermediaries, tour operators, travel agencies and tourist guides; rent-a-car; cultural services and; leisure and recreation activities [19] this route has potential to be enriched with spots that are offering experience of local tradition, such as cuisine (to establish more local food restaurants, currently most visited are restaurant on the main axe near tekke with local fish), shops with local products (currently it is possible to buy in the improvised market on the main axe), cultural or spiritual experience (tekke) etc. All existing are currently set between points 6 and 7 .

The state of the site is not currently at a satisfactory level as the main axis of movement is disturbed by visible cables, unregulated parking, and an informal market. One example is the approach towards the hammam (point 4) and the bridge, both of which are national monuments.

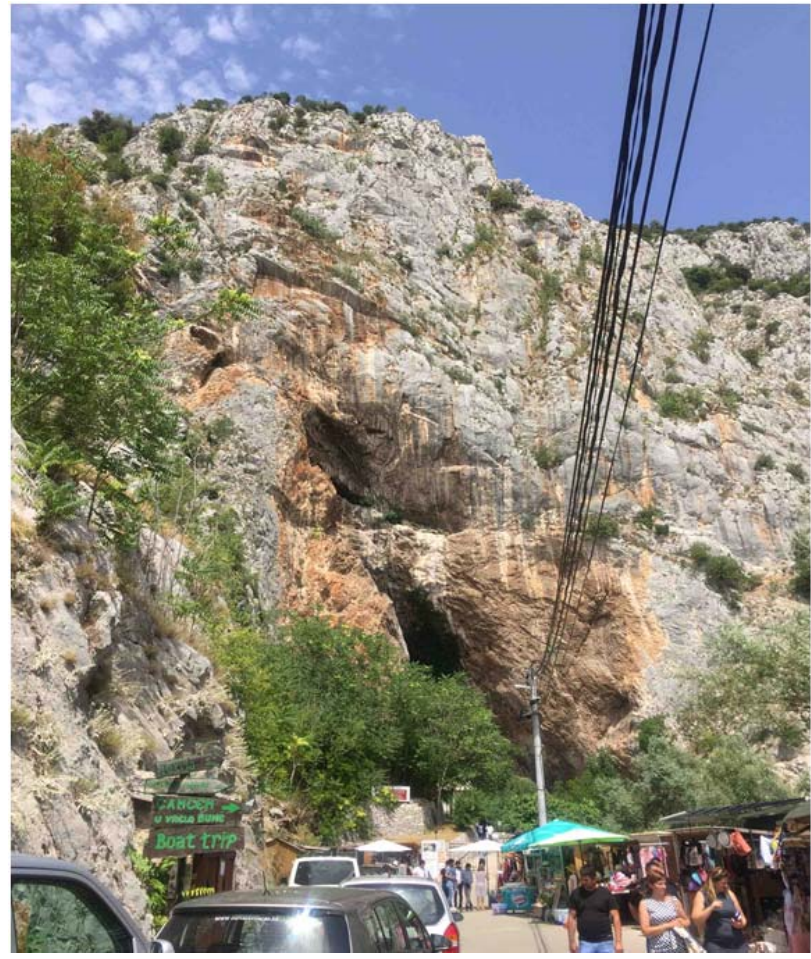

Figure 6. Blagaj: main axis of movement with visible cables, unregulated parking, and an informal market (Source: author)

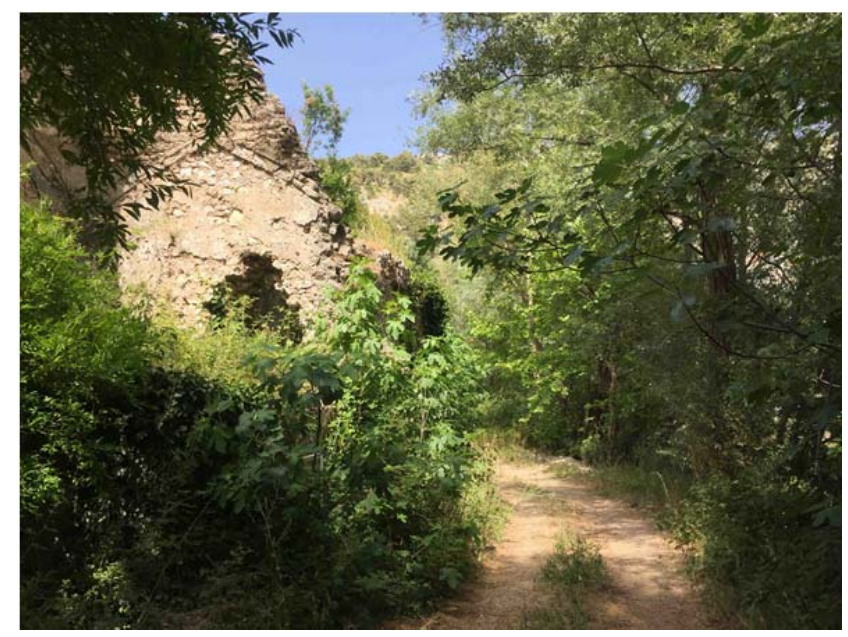

Figure 7. Hammam in Blagaj showing a lack of maintenance and the poor presentation of the national monument (Source: Sabanovic N.) 


\section{Conclusion and Vision}

The historical areas of Blagaj, Travnik, and Jajce abound with valuable natural and manmade features. Because of the value of their urban fabric, they are protected sites at the national level: the cultural landscape of Plava Voda in Travnik; the historic site of Jajce; and the historic urban area of Blagaj. Blagaj and Jajce have both been inscribed on the UNESCO tentative list as "natural and architectural ensembles." Their historic cores are inseparable from the natural environment and their distinguished character takes the form of cultural landscapes.

These sites have the potential to be of great interest to visitors and tourists, since cultural landscapes are sites that integrate many diverse points of interest; they could become a driving force for tourism development in the region. Managed sustainably, tourism can help encourage preservation and be a source of income.

Well managed tourism encourages heritage preservation and may contribute to the preservation of the wider area, including cultural landscapes. However, in Bosnia and Herzegovina preservation and heritage management strategies have not accelerated tourism development.

The National Monuments of Bosnia and Herzegovina are under state jurisdiction and each decision prepared by the Commission to Preserve National Monuments also contains a set of recommendations for future action. On the ground, the situation is unsatisfactory and many actions have been contrary to the formal recommendations made due to a lack of proper heritage management and conservation plans, as well as failures in strategic implementation. As such, many historic sites have seen unregulated building activity, inappropriate interventions, and illegal construction, etc., making the sites less attractive. Until now there has been no overarching action that considers all elements belonging to such a site under the same broad frame, but rather selective cases of preserving single monuments. Additionally, low community participation, and slow bureaucratic processes are some of the weakness of the management strategies used.

The majority of the elements in the selected sites or single monuments, proclaimed as national monuments and including natural settings, are located at very short distances from each other. This favours the development of tourist routes that can connect and properly present them. Tourist routes in a cultural landscape should be arranged to highlight the experience of the place, going beyond a simplistic walk from one monument to another, and including some of the intangible character of a place, such as local habits, tradition, cuisine, crafts, or else some of the history, stories, and folklore.

However, insufficient development of transport infrastructure and parking spaces; weak tourist programs with inadequate presentation of cultural heritage; and limited accommodation capacity are some of the main constraints of tourism development. Tourism development should see the wider area considered holistically to better encourage sustainability. Tourism development also requires sufficient services to encourage better treatment of heritage assets.

Public involvement is also important to ensure awareness among local inhabitants about the value of their heritage. Local people are important in ensuring places are sustainable in the future. Tourism does not necessarily ensure successful preservation and can also be harmful, but it has the potential to strengthen and bring benefits to historic sites so that they can be preserved for the future. Increased services and facilities would provide the possibility of accommodating more and different types of tourists and tourist groups. To provide possibilities for people to experience the cultural landscapes of the three selected sites, a number of buildings need to be restored and used as hotels. However, restoration should be conducted in a highly professional manner, with integrity and authenticity, and respecting local and heritage values.

\section{References}

[1]. Rodwell, D. (2007). Conservation and sustainability in historic cities. John Wiley \& Sons.

[2]. UNESCO, W. (2011). Recommendation on the historic urban landscape. Retrieved from: https://whc.unesco.org/uploads/activities/documents/a ctivity-638-98.pdf [accessed: October 5, 2019].

[3]. Report Federal institution for statistic. (2018). Retrieved from :

http://www.bhas.ba/?option=com content\&view=arti cle\&id=46\&lang=en [accessed: December 5, 2019].

[4]. Orbasli, A. (2002). Tourists in historic towns: Urban conservation and heritage management. Taylor \& Francis.

[5]. Basler, Đ. (1972). Arhitektura: kasnoantickog doba u Bosni i Hercegovini. Veselin Masleša.

[6]. Imamović, E. (2005). Arheološka slika Blagaja, stolnog mjesta Stepana Vukčića Kosače. Herceg Stjepan Vukčić Kosača I njegova doba, Maglajlić M. (Eds.), 9-17.

[7]. Commission to Preserve National Monuments of Bosnia and Herzegovina. (2005). Decisions on Designation of Properties as National Monuments. Retrieved from: http://old.kons.gov.ba/main.php?id_struct=6\&lang $=1$ \&action=view\&id=2558 [accessed: October 5, 2019].

[8]. Kreševljaković, H. (1953). Stari bosanski gradovi. Naše starine, 1, 7-45. 
[9]. Korkut, H. K. D. M. (1961). Travnik u prošlosti 14641878.

[10]. Udovičić, M. (1973). Travnik u vrijeme vezira: 1699-1851. Zavičajni Muzeĭ Travnik.

[11]. Redžić, H. (2009). Srednjovjekovni gradovi u Bosni i Hercegovini. Sarajevo Publishing.

[12]. Mazalić, Đ. (1952). Stari grad Jajce, Glasnik Zemaljskog muzeja u Sarajevu, 7(62).

[13]. Mulalić-Handan, M. (2007). Upravljanje historijskim gradskim područjem Jajca. Baština (III), 377-428.

[14]. Strategija razvoja općine Jajce za period 2014-2023. (2013). Retrieved from: https://www.opcinajajce.ba/2015-05-12-20-01-28/dokumenta/294strategija-razvoja-opcine-jajce-2014-2023/file.html [accessed 15 December 2019].

[15]. Commission to Preserve National Monuments of Bosnia and Herzegovina. (2013). Decisions on Designation of Properties as National Monuments. Retrieved from:

http://old.kons.gov.ba/main.php?id struct $=6 \&$ lang=1 \&action=view\&id=3731 [accessed: October 5, 2019].
[16]. Kudumovic, L. (2020). Cultural Landscapes and Preservation: The Case Studies of Blagaj and Travnik. Cities and Cultural Landscapes: Recognition, Celebration, Preservation and Experience, Bailey, G. Defilippis, F. Korjenic, A. \& Čaušević A. (Eds.), Cambridge Scholars Publishing, 258-276.

[17]. Charter, M. (1999). Managing Tourism at Places of Heritage Significances. Retrieved from: https://www.icomos.org/charters/tourism_e.pdf [Accessed: May 5, 2019].

[18]. Taylor, K. (2014). Cities as cultural landscapes. Reconnecting the City: The Historic Urban Landscape Approach and the Future of Urban Heritage, 179-202.

[19]. Costa, C. (2006). Tourism planning, development and the territory. Tourism Management DynamicsTrends, management and tools, Dimitrios, B., Costa, C.(Eds.), Oxford: Elsevier Butterworth-Heinemann, 236-243. 